\title{
Circumstances of Mitigation and Aggravation of the Legalization of Revenue Received from Criminal Activities
}

\author{
Farkhod Maratovich Fazilov ${ }^{1}$ \\ ${ }^{1} \mathrm{PhD}$, Senior lecturer of Criminal law, criminology and fight against corruption Department of the Tashkent \\ State University of Law, Uzbekistan, Tashkent \\ Email :fazilov.farhod@gmail.com \\ ORCID: https://orcid.org/0000-0001-8603-1948
}

\begin{abstract}
This article analyzes Circumstances of mitigation and aggravation of the legalization of revenue received from criminal activities. Just punishment is the foundation of crime prevention (1). The Article 42 of the Criminal Code establishes that punishment is a measure of coercion applied on behalf of the state by a court verdict to a person found guilty of committing a crime, and consists in the deprivation or restriction of certain rights and freedoms of the convicted person as prescribed by law.
\end{abstract}

Key words: Circumstances of mitigation and aggravation, Criminal Code, guilty of committing a crime

Article Received: 16th October, 2020; Article Revised: 30th December, 2020; Article Accepted: 08th January, 2021

\section{Introduction}

Just punishment is the foundation of crime prevention (1). The Article 42 of the Criminal Code establishes that punishment is a measure of coercion applied on behalf of the state by a court verdict to a person found guilty of committing a crime, and consists in the deprivation or restriction of certain rights and freedoms of the convicted person as prescribed by law.

The list of criminal acts is established by law. When determining criminal liability for various crimes, a differentiated approach is used. For each criminal act, a specific penalty is provided by the Special Part of the Criminal Code.

The criminal law does not define the circumstances that mitigate and aggravate the punishment.

Analyzing the terminology used to refer to these circumstances in the criminal legislation of foreign countries, it can be noted that it also does not differ in uniformity.

The Criminal Code of the Republic of Belarus and the PRC they are referred as circumstances mitigating or aggravating the liability (2), in the US, they are called mitigating and aggravating factors (3), in the Criminal Code of France and Switzerland - the circumstances softening and aggravating punishment, in the Criminal code of Spain, circumstances mitigating and aggravating the punishment and guilt (4).

Circumstances that mitigate and aggravate punishment are conditions that characterize the degree of public danger of the committed crime and (or) the identity of the perpetrator, affecting the reduction or strengthening of the punishment.

Failure to recognize a circumstance as mitigating or aggravating the punishment should be reasoned in the descriptivemotivational part of the verdict.

Under the circumstances of mitigating or aggravating the sentence, the means of individualization of punishment established in law or recognised as such by the court (only extenuating circumstances) should be understood, evidence of decrease or increase of public danger of the crime and the identity of the perpetrator, or the principle of humanity should be taken into account when 
determining the degree of the punishment for every person convicted of a crime (5).

\section{Materials and Method}

In the course of the study, methods such as historical, systemic-structural, comparative-legal, logical, specifically sociological, complex research of scientific sources, induction and deduction, analysis of statistical data were applied.

\section{Results}

The most common is the classification of mitigating and aggravating circumstances on the basis of their belonging to one of the parties of the crime. So, I.I. Karpets believed that mitigating and aggravating circumstances can relate to the object, objective side, subject and subjective side of the crime (6).

This classification has been fairly criticized due to the fact that it has other significant shortcomings. As rightly pointed out by G.L. Krieger, "attempts to group mitigating and aggravating circumstances by individual elements of the crime do not contribute to understanding the content and meaning of these circumstances". In addition, most of the mitigating and aggravating circumstances relate to both the act and the identity of the perpetrator and the subjective side of the crime. In addition, the circumstances under consideration do not fit into the scheme, which is based on elements of the corpus delicti, since "many of them characterize the identity of the perpetrator - a category broader than such an element of the corpus delicti as the subject of the crime"(7).

M.M. Babaev and G.S. Gaverov define three types of mitigating and aggravating circumstances, highlighting the circumstances related to:

a) to the objective and subjective properties of the committed socially dangerous act;

b) to the identity of the subject;

c) to the reasons and conditions that are associated with this criminal manifestation
(8).

According to V.I. Tkachenko and M.A. Scriabin, the following types of mitigating and aggravating circumstances should be distinguished:

a) characterizing the crime only;

b) characterizing the person only

c) characterizing both the identity of the perpetrator and the crime (9).

The Article 55 of the Criminal Code of the Republic of Uzbekistan (10) provides for 9 mitigating circumstances (11):

a) surrender, sincere repentance or active assistance in solving the crime;

b) voluntary compensation for the damage caused;

c) the commission of a crime as a result of the prevailing difficult personal, family or other conditions;

d) the commission of a crime under duress or by virtue of material, official or other dependence;

e) committing a crime in a state of strong emotional extreme caused by violence, grave insult or other unlawful actions of the victim;

f) committing a crime when exceeding the limits of the legality of the necessary defense, extreme necessity, causing harm when detaining a person who has committed a socially dangerous act, justified professional or economic risk;

g) commission of a crime by a juvenile;

h) commission of a crime by a pregnant woman;

i) the commission of a crime under the influence of unlawful or immoral behavior of the victim.

The law does not limit the list of circumstances that mitigate the punishment. Therefore, mitigating and other circumstances not provided in this article (for example, committing the first crime, constitute a danger to the public, the presence of the defendant's minor child, the commission of a crime by reason of compassion, guilty of rendering medical and other aid to the victim immediately after the crime, etc.) can also be taken into 
account in sentencing. The recognition of such a circumstance as mitigating the punishment must be reasoned in the sentence (12).

In the theory of criminal law and legislation, the circumstances provided in the Article 56 of the Criminal Code of the Republic of Uzbekistan were referred in various ways, for example, "affecting the degree of guilt"(13), "increasing guilt"(14), "aggravating the crime"(15), "aggravating the degree of responsibility"(16).

The Article 56 of the Criminal Code of the Republic of Uzbekistan provides 14 circumstances that aggravate the punishment (17):

a) in relation to a woman who is known to the perpetrator to be in a state of pregnancy;

b) in relation to a juvenile, an elderly person or a person who is in a helpless state;

c) in relation to a person or his close relatives in connection with the performance of his official or civil duty;

d) in relation to a person who is in material, official or other dependence on the perpetrator;

e) with extreme cruelty;

f) in a generally dangerous manner;

g) with the use of a juvenile or a person who is known to be suffering from a mental illness by the guilty;

h) which caused the occurrence of serious consequences;

i) using the conditions of a public disaster or during a state of emergency or in the process of mass riots;

j) out of mercenary or other base motives;

$\mathrm{k}$ ) on the grounds of racial or national enmity or discord;

1) by prior agreement of a group of persons, an organized group or a criminal community;

m) repeated or new intentional crime after conviction for a previously committed intentional crime;

$n$ ) in a state of alcoholic intoxication or under the influence of narcotic drugs, their analogues, psychotropic or other substances that affect intellectual and volitional activity.

The list of aggravating circumstances is exhaustive. However, the court may not take into account these circumstances if there are good reasons and they must be provided in the verdict.

Qualifying signs of a crime may not be aggravating circumstances.

\section{Conclusion}

Analyzing such a crime as the legalization of revenue from criminal activities, we come to the conclusion that the very disposition of the Article 243 of the Criminal Code does not contain signs that mitigate and aggravate the legalization of revenue received from criminal activities

Since the adoption of the Law of the Republic of Uzbekistan "On countering the legalization of revenue received from criminal activities, the financing of terrorism and the financing of the proliferation of weapons of mass destruction" dated August 26, 2004(18), a state system for countering the legalization of criminal revenue has been systematically created in the country, which is aimed to meet modern international standards.

However, none of these sources give qualifying signs of a crime (19-21).

At the same time, the criminal legislation of a number of countries, namely, the Russian Federation, Kazakhstan, Switzerland, France, etc. indicate the organization of money laundering by a group of persons, an organized criminal group, repeatedly, etc. as qualifying signs for such circumstances.

\section{References}

[1] Resolution of the Plenum of the Supreme Court of the Republic of Uzbekistan "On the practice of assigning criminal penalties by courts" No. 1 dated February 3, 2006. Mode of access: http://www.lex.uz/acts/1455974 
[2] Dolinenko L.A. Mitigating circumstances under the current criminal law and in court practice. Educational manual. - Irkutsk. 1980 - p. 81 .

[3] Access mode. - https://avalonlaw.ru/

[4] Legislationline.org - Portal of Legislation of the OSCE Region / Criminal law.

[5] Myasnikov O.A. Mitigating and aggravating circumstances in Russian criminal law: Dissertation of the Candidate of Legal Sciences: 12.00.08. - Moscow, 2001. - p. 28.

[6] Myasnikov O.A. Mitigating and aggravating circumstances in Russian criminal law: Dissertation of the Candidate of Legal Sciences: 12.00.08. - Moscow, 2001. - p. 28.

[7] Krutikov L.L. Mitigating and aggravating circumstances in criminal law (Questions of theory). Voronezh. 1985. - p. 110.

[8] Myasnikov O.A. Mitigating and aggravating circumstances in Russian criminal law: Dissertation of the Candidate of Legal Sciences: 12.00.08. - Moscow, 2001. - p. 36.

[9] Tkachenko V. General principles of sentencing // The Russian Justice. 1997. - No. 1. - P. 10, Scriabin M.A. General principles of sentencing and their application to minors. Kazan. 1988. p. 76-77.

[10] Dolinenko L.A. Mitigating circumstances under the current criminal law and in court practice. Educational manual. Irkutsk. - 1980 - p. 81.

[11] ++https://www.lex.uz/acts/111457?O NDATE $=01.04 .1995 \% 2000 \# 171225$

[12] Resolution of the Plenum of the Supreme Court of the Republic of Uzbekistan "On the practice of assigning criminal penalties by courts". No. 1 dated February 3, 2006.

[13] Bazhanov M.I. Mitigating and aggravating circumstances in the imposition of punishment // Questions of state and law. - M., 1974. - p. 250.

[14] Criminal law. General part: Textbook / Hertsenzon A.A., Isaev M.M., Piontkovsky A.A., Utevsky B.S; Scientific ed.: Menshagin V.D., 4th ed., reprint - M.: Legal ed., - p. 575.

[15] Demidov Yu. Imputation of aggravating circumstances // $\mathrm{M}$. 1964. No. 6. - p. 28.

[16] Fatkullin F.I. General problems of procedural evidence. pp. 57-58. Kazan, 1974. Naumov A.V. Russian Criminal Law: General part. Course of lectures: In 2 volumes. Vol. 1 // A.V. Naumov // Moscow: Legal lit., - 2007. - p. 98.; Brilliantov A.V. Commentary on the Criminal Code of the Russian Federation: in 2 vols. Vol. 1 // A.V. Brilliantov // Prospect, - 2015. [electronic source] // SPS Consultant Plus.

[17] https://www.lex.uz/acts/111457?ON DATE $=01.04 .1995 \% 2000 \# 171225$

[18] Law of the Republic of Uzbekistan "On countering the legalization of revenue received from criminal activities, the financing of terrorism and the financing of the proliferation of weapons of mass destruction", August 26, 2004, No. 660-II. Mode of access: http://www.lex.uz/acts/284542

[19] X.Ochilov, D.Kamalova, Criminal responsibility for inchoate Offence according criminal code of the republic of Uzbekistan. Tashkent State University of Law, Republic of Uzbekistan. International Journal of Advanced Science and Technology. Vol. 29, No. 5, (2020), pp. 17291737.

[20] Fazilov F.M..The general concept of legalization of revenue from criminal activities ISJ Theoretical \& Applied Science, 11 (79), 255-259. http://tscience.org/arxivDOI/2019/1179/PDF/11-79-54.pdf 
[21] S.S.Niyozova. Reasons for Suicide and the Issue of Responsibility. International Journal of Pharmaceutical Research | Dec 2020 | Vol 12 | Supplementary Issue 3 p. 528.

[22] Kh.R. Ochilov, The Object and Its Significance in Crimes of Looting Other's

[23] Property by Using Computer Tools PSYCHOLOGY AND EDUCATION (2021) 58(1): 10571068, pp. 1057-1068. 